\title{
Soil Quality Indicators Effects on Alfalfa Productivity at El-Sadat Center Soil Conditions
}

\author{
Zaid MS, Eid AH, Abd El Wahab AM and Wanas M \\ Department of Soil and water, Al-Azhar University, Egypt
}

Submission: May 15, 2017; Published: June 16, 2017

"Corresponding author: Wanas M, Soil and water Department, Al-Azhar University, Egypt, Email: Magro_modeller@yahoo.com

Abstract

This study was carried out in El-Sadat center, Al-Monufyia Governorate during 2013/2015 seasons, to study the relationship between physical and chemical soil quality indicators on alfalfa and bean productivity. Eight soil samples of six locations have been sampling to a depth of $30 \mathrm{~cm}$. All samples collected for each region separately, and analyzed for fourteen physical indicators viz. CS, FS, S and clay, BD, real density, hydraulic conductivity, field capacity, wilting coefficient, slowly drainable porosity, Quickly drainable porosity, mean Wight diameter, water holding porosity and total porosity; as well as, seven chemical indicators viz. pH, electric conductivity, organic matter, cation exchange capacity, calcium carbonate, available potassium and total nitrogen. Wheat productivity is the basic factor in determining soil quality (SQ) using parameters or soil quality indicators.

Results showed that, the soil planted (alfalfa crop) were more affected (significant correlation) on the production of four indicators namely: $\mathrm{pH}\left(0.68^{*}\right)<\mathrm{TN}\left(0.65^{*}\right)<\mathrm{OM}(0.52)<$ clay $(0.50)$. Regarding, the soil planted (crop beans) were more affected (significant correlation) on the production of four indicators namely: FS and silt, and slowly drainable porosity, and CaCO3 and most impact on production: silt $(-0.77 *)<\mathrm{FS}$ $\left(0.647^{*}\right)<\mathrm{CaCO}_{3}\left(-0.605^{*}\right)<$ slowly drainable porosity $(0.53)$.Results also, clear that there are in significant relationship among physical parameters and alfalfa equivalent yield. Results added that, insignificant linear relationship correlation was observed between alfalfa productivity and most of chemical parameters under study such as ( $\mathrm{EC}, \mathrm{CaCo}_{3}, \mathrm{CEC}$, and Av. $\left.\mathrm{k}\right)(\mathrm{r}=-0.021,0.490,-0.470$, and 0.000$)$ respectively, on the opposite, both of $\mathrm{PH}, \mathrm{OM}$ and T.N indicators showing a significant positive linear relationship correlation $(\mathrm{P}<0.05, \mathrm{r}=0.680,0.520,0.650)$ respectively.

Keywords: Physical SQI; Alfalfa; El-Sadat center; OM; Productivity

\section{Introduction}

Soil is considered as the main source in providing essential plant nutrients, water reserves and a medium for plant growth. The definition of soil quality is the ability of a soil to perform within an ecosystem and soil use, to preserve both of biological activities, and environmental quality, as well as encourage plants, animals, and human health [1]. Soil quality (SQ) depends in part on the natural composition of the soil. The definition of SQ discovered in the early 1990s Wienhold et al. [2] and defined as the ability of a soil to perform within an ecosystem and soil use, to preserve both of biological activities, and environmental quality, as well as encourage plants production [3]. Soil quality is considered one of the best methods for soil quality determination due to ease of use, flexibility and quantification. These indices represent the cumulative effects of different soil properties (physical, chemical and ecological) as an index from the role of each indicator in soil quality $[4,5]$.
Soil physical quality is measured by soil indicators such as available water holding capacity (AWHC), relative field capacity to water saturation (RFC), macro porosity, bulk density (BD), and many others [6]. Chemical Indicators of soil quality the purposed include on cation exchange capacity (CEC), contaminant presence (CP), (EC) exchangeable sodium, pH, Av. k, and Av. P.... etc. Many researchers have proposed various SQ parameters $[1,7,8]$ that can be easily measured and they are sensitive to change of soil condition and therefore, they must be able to identify appropriated sustainable soil conditions $[9,10]$. Liu et al. [11] established SQ index depending on twenty-six soil physical, chemical and microbiological properties in a paddy soil of china by using both TDS and MDS methods.

In general, most researchers used a set of predefined soil indicators suggested by Gomez et al. [9] and Shukla et al. [12] to 
determine SQ and sustainability of agricultural land. The process of degradation in Egypt has intensified due to low farmers' information of agricultural soil conditions, and decrees of proper equipment's. Under these conditions, the soil quality is often influenced by limiting factors such as high temperature, poor soil fertility, low available holding capacity of water (AWHC), organic carbon of soil (SOC) and high concentrations of salt and $\mathrm{pH}$. When soil quality indicators are in the optimum range, crop yield response would be optimal (maximum obtainable yield) with reduced soil degradation [6]. (Table 1)

Table 1: The properties of studied sites.

\begin{tabular}{|c|c|c|c|c|c|c|c|c|c|}
\hline No. & Study Site & Location & Depth (Cm) & Sand $(\%)$ & Silt (\%) & Clay (\%) & BD & EC & PH \\
\hline 1 & Albarka basin and Almadaor. & $30^{\circ} 23^{\prime} 58^{\prime \prime} \mathrm{N} 30^{\circ} 50^{\prime} 8^{\prime \prime} \mathrm{E}$ & $0-30$ & 31 & 34 & 35 & 1 & 0.85 & 7.14 \\
\hline 7 & Khatatba village & $31^{\circ} 45^{\prime} 10^{\prime \prime} \mathrm{E} 31^{\circ} 25^{\prime} 8^{\prime \prime} \mathrm{N}$ & $0-30$ & 53.5 & 22.8 & 23.7 & 1.31 & 0.69 & 7.36 \\
\hline 8 & Abu Nashaba .v & $31^{\circ} 50^{\prime} 12^{\prime} \mathrm{E} 31^{\circ} 31^{\prime} 10^{\prime \prime} \mathrm{N}$ & $0-30$ & 48.62 & 17.8 & 33.59 & 1.34 & 0.26 & 7.6 \\
\hline 9 & Alakhmas west & $30^{\circ} 59^{\prime} 15^{\prime \prime} \mathrm{E} 30^{\circ} 26^{\prime} 20^{\prime \prime} \mathrm{N}$ & $0-30$ & 48.48 & 22.4 & 29.76 & 1.29 & 0.29 & 7.5 \\
\hline 10 & Alakhmas east & $30^{\circ} 50^{\prime} 9^{\prime \prime}$ E $30^{\circ} 25^{\prime} 61^{\prime \prime} \mathrm{N}$ & $0-30$ & 49.11 & 22.1 & 26.4 & 1.25 & 0.26 & 7.26 \\
\hline 11 & Altranh west & $30^{\circ} 40^{\prime} 13^{\prime \prime} \mathrm{E} 30^{\circ} 22^{\prime} 50^{\prime \prime} \mathrm{N}$ & $0-30$ & 51.5 & 19.2 & 24.2 & 1.35 & 0.37 & 7.3 \\
\hline
\end{tabular}

A character's soil physical affect crop productivity by many ways. Development and growth of plant are heavily evaluated by the soil's texture, BD, porosity, WHC, and the presence or absence of hard pans. These characters are all improved by adding of organic matter to soils. Also the previous characters impress relationships of soil and plant water. The distribution of water at the soil surface is important because it determines both SQ of surface and groundwater, in addition the amount of water that will be available for plant growth. Therefore, aim of the present study is to study the relationship among physical and chemical SQ indicators as affected on alfalfa productivity under El-Sadat center soil conditions.

\section{Materials and Methods}

The current investigation was carried out in El-Sadat center, Al-Monufyia Governorate during 2013/2015 season to: study the relationship among physical and chemical SQ indicators with alfalfa productivity.

\section{The materials and methods of this investigation are presented as follows}
a) Map and locations of samples
b) Data of location
c) Laboratory analysis
d) The physical analysis of soil
e) The chemical analysis of soil

In this study, we measured physical and chemical SQ. As for, physical indicators include the following; Texture (T), bulk density (BD), total porosity (TP), available water (AW), aggregates stability (AS), (HC), field capacity (FC), wilting coefficient (WC). Regarding, the chemical indicators include the following; $\mathrm{pH}$, electric conductivity (EC), organic matter (OM), cation exchange capacity (CEC), total calcium carbonate (TC), total nitrogen $(\mathrm{TN})$, available potassium $(\mathrm{AV}-\mathrm{K})$ were determined according to Page et al. [13].

\section{Maps and location of samples}

The study sites are located within El-Sadat center, AlMonufyia Governorate. Before we begin sampling process was brought one Map Survey for the study area for Al-Monufyia governorate, the samples were signed on map and took samples from seven locations.

\section{Data of Location}

Eight samples of six locations have been sampling to a depth of $30 \mathrm{~cm}$ and collected all the data for each region separately from the various management processes of the plant (crop), for example tillage and land preparation for agriculture, the process of application fertilizers mineral or Organic, the irrigation system and his condition (source), The drainage system and his condition, the high level of ground water, topographic, and all the data about the area under investigation. Crop has been planted (alfalfa). Whereas was the follow-up crop from planting to harvest, and follow up the root system and taken plants from each area and measure the root length and spread into the soil body, and taking photographic images to the length of the plant root (at a rate of twice each field, after one month and two months from planting). At harvest stage, the crop productivity per feddan for each field was calculated separately and compares it to similar crop grown in another field with different soil texture. Whereas productivity is the basic factor in determining soil quality using parameters or soil quality indicators.

\section{Laboratory Analysis}

Determination of the physical and chemical properties

\section{Soil physical analysis}

Particle size distribution: Was determined according to Klute [14].

Particle density: Was determined according to Klute [14].

Soil bulk density: was determined according to Klute [14].

Total porosity (n): was calculated according to Klute [14]. 
$\mathrm{N}=\left(\mathrm{Y}^{\mathrm{s}}-\mathrm{Y}^{\mathrm{d}} / \mathrm{Y}^{\mathrm{s}}\right) \times 100$

Hydraulic conductivity coefficient: was determined according to the Darcy's equation Klute [14]:

$\mathrm{K}=(\mathrm{QL} / \mathrm{HAT})$

Where: K= Hydraulic Conductivity coefficient $\mathrm{cm} / \mathrm{h} Q=$ volume the filtrate $(\mathrm{cm} 3)$.

$\mathrm{L}=$ length of the soil column $(\mathrm{cm})$. $\mathrm{H}=$ length of the water column $(\mathrm{cm})$.

$A=$ area of the tube $(\mathrm{cm} 2) . T=$ Time $(\mathrm{Sec})$.

FC, PWP and AW: Were determined according to Saxton \& Rawls [15]

$$
\mathrm{AWC}=\mathrm{FC}-\mathrm{PWP}
$$

Where: (FC) is Field capacity; (PWP) is permanent wilting point.

Aggregates stability: was determined according to Six et al. (2002) as follows: MWD $=\sum \mathrm{Xi} \mathrm{Wi}$ $--(3.4)$.
Where: $\mathrm{I}=1, \mathrm{X}=$ mean diameter of the considered fraction $\mathrm{mm}, \mathrm{W}=$ weight of the dry sieving fraction $\mathrm{g}$.

\section{Soil Chemical Analysis}

Was determined according to Page et al. [13].

\section{Statistical analyses}

Statistical analysis for data was don using SPSS V. 21 (35) (2014) and Microsoft Excel (39) (2007). All the figures were obtained using Sigma Plot V. 12.0(40) (2012).

\section{Results and Discussion}

\section{Soil Physical Indicators}

Soil texture: Table (2) showed that the studied soil samples have different soil textural classes i.e. a relatively fine texture (clay loam soil samples 8), a relatively medium (loam, sandy clay loam and sandy clay soil samples 4, 12, 20, 21, 22, 24, 13 for alfalfa. these widely variations are more relative to the soil origin, intensity of geo-chemical weathering, vertical or horizontal depositional pattern, nature of both depositional media and mechanism of transportation.

Table 2: Soil texture, BD, TP, HC, WP and FC of soil samples under study.

\begin{tabular}{|c|c|c|c|c|c|c|c|c|c|c|c|}
\hline \multirow{2}{*}{ Crops } & \multirow{2}{*}{ Sample } & \multicolumn{4}{|c|}{ Particle Size Distribution (\%) } & \multirow{2}{*}{ Textural Class } & \multirow{2}{*}{$\begin{array}{c}\text { B.D G/ } \\
\text { Cm3 }\end{array}$} & \multirow{2}{*}{ T.P \% } & \multirow{2}{*}{ H.Ccm/H } & \multicolumn{2}{|c|}{ Soil Moisture Constants } \\
\hline & & C.S & F.S & Silt & Clay & & & & & W.P\% & F.C\% \\
\hline \multirow{8}{*}{ Alfalfa } & $\mathrm{S} 4$ & 6.5 & 32.5 & 37 & 24 & $\mathrm{~L}$ & 1.2 & 54.72 & 4.7 & 12.9 & 28.30 \\
\hline & S12 & 4.5 & 41.5 & 20 & 34 & SCL & 1.37 & 49.6 & 4.1 & 12.8 & 26.50 \\
\hline & S13 & 5.3 & 41.7 & 17 & 36 & SC & 1.24 & 48.15 & 4.2 & 12.15 & 26.25 \\
\hline & S20 & 7.2 & 38.4 & 20.4 & 34 & SCL & 1.46 & 44 & 0.83 & 8.5 & 19.10 \\
\hline & $\mathrm{S} 21$ & 7.9 & 42.7 & 19.8 & 29.6 & SCL & 1.3 & 52.3 & 8.31 & 14 & 29.40 \\
\hline & $\mathrm{S} 22$ & 12.1 & 41.2 & 22.1 & 24.6 & SCL & 1.33 & 48.2 & 0.94 & 9.2 & 21.30 \\
\hline & $\mathrm{S} 23$ & 8.4 & 36.1 & 23.9 & 31.6 & $\mathrm{CL}$ & 1.35 & 49.4 & 4.4 & 11.3 & 22.00 \\
\hline & S24 & 8.3 & 39.3 & 19.4 & 33 & SCL & 1.30 & 51.8 & 5.82 & 12.7 & 27.00 \\
\hline
\end{tabular}

Where: C.S: Cores Sand; F.S: Fine Sand; T.C: Texture Class; F.C: Field Capacity; BD: Soil Bulk Density; R.D: Real Density (Particle Phase Density); H.C: Hydraulic Conductivity; Por: Porosity; CL: Clay Loam; SCL: Sandy Clay Loam; L: Loam; SL: Sandy Loam; SC: Sand Clay

Soil bulk density (BD): Data of table (2) shows the studied samples have different soil physical properties. Soil bulk density is the important parameter to evaluate soil physical indicators such as total porosity and void percentages. It is role different factors including organic matter, total porosity, and biological activity, particle packing density, carbonate and soil moisture contents. Results in the previous Table showed that studied soil samples were ranged from 1.20 to $1.46 \mathrm{~g} / \mathrm{m} 3$ for bulk density. The lowest value $(1.20 \mathrm{~g} / \mathrm{m} 3)$ was obtained in the soil sample 4; on the other hand, the highest value $(1.46 \mathrm{~g} / \mathrm{m} 3)$ was recorded in sample 20. The general trend of change in bulk density with different studied sample was an increase with legumes crops. This may indicate an increase in secondary carbonates that would enhance the formation of the soil aggregates. However, soil bulk density values of soil samples tend to increase with depth that resulting from the deepening legumes (alfalfa) roots. This is probably to the increase of clay fraction and soil compaction with legumes roots.
Soil porosity: Total porosity is an index of the relative volume of pores in soil and is used to evaluate soil structure. Results of Table 2 indicated that, soil samples were ranged between $44 \%$ and $55.22 \%$ for total soil porosity. The lowest value was recorded in soil sample 20, within crop total porosity tends to be higher in the soil sample S4(54.72\%), results added that total soil porosity increases with increasing clay and organic matter content, but it decreases with increasing of soil compaction in the deeper roots comparing with surface roots, these results indicated that total porosity is mainly affected by soil physical properties and partly be both organic matter content and soil compaction.

Soil hydraulics conductivity (HC): Soil hydraulics conductivity is an important parameter in the planning of water use, irrigation, drainage as well as in leaching of salt affected soils in soil reclamation. It measures the rate of water conduction, water movements in the saturated flow principally through macrospores. The determined values of hydraulics 
conductivity of the studied soil samples are presented in Table 2. The obtained values of Soil hydraulics conductivity ranged between $0.83 \mathrm{Cm} / \mathrm{h}$ and $12.5 \mathrm{Cm} / \mathrm{h}$, the lowest was obtained in sample $\mathrm{S} 20(0.83 \mathrm{Cm} / \mathrm{h})$. On the opposite, the highest value was obtained in sample $\mathrm{S} 21(8.31 \mathrm{Cm} / \mathrm{h})$. In general, the variations in the soil hydraulic conductivity can be attributed to the influence of soil quality and porosity.

Soil moisture parameters (FC, WP): Soil moisture characteristics are very important parameter to determine the irrigation requirements of the cultivated crop in arid and semiarid regions as well as selection of the cultivated crops. FC and WP were affected by many factors such as soil mineralogical composition, total soluble salts and the exchangeable Captions, the results of samples are illustrated in Table 2, found that field capacity and wilting point differ from one physiographic unit to another values of moisture content at field capacity ranged between 19.10 and $39.79 \%$. The lowest value was recorded in S16 (21.29\%). on the other side, the highest value was found in S21 (29.40\%). Values of moisture content at field capacity tend to increase with deeper and have an irregular distribution in the other soil samples. Values of wilting point for soil samples in different area, were ranged between 8.5 and $15.2 \%$. The lowest value was recorded in S20 (8.5\%), while the highest value was found in S4 (12.9\%). Values of FC and WP tend to increase with deeper and have an irregular distribution in the other soil samples. These results may be suggested that they are positively related to soil fine particles (clay content).

\section{Soil Chemical Indicators}

\section{Soil PH}

According the values of $\mathrm{pH}$ for soil samples under study are recorded in Table 3. The obtained values of Soil $\mathrm{pH}$ ranged between 7.12 and 8.10, the lowest was obtained in sample S12 (7.12), while, the highest value was obtained in samples S4 (8.10) for alfalfa crop. Considering the change in $\mathrm{pH}$ values, data revealed that a slightly increase with S4, S20, and S23 but a decrease was noticed in S12, S19 and S21 and no certain trend can be observed in some other soil samples (S22). Soil $\mathrm{pH}$ values may be indicated that these studied soils are base saturated since all their $\mathrm{pH}$ values are over 7.0.

Table 3: Chemical indicators of the studied soil samples.

\begin{tabular}{|c|c|c|c|c|c|c|c|c|}
\hline Crop & Sample & $\begin{array}{c}\text { p H } \\
\text { 01:02.5 }\end{array}$ & $\begin{array}{c}\text { E.C } \\
(\mathrm{ds} / \mathrm{m})\end{array}$ & $\begin{array}{c}\text { T.N } \\
\text { (Mg/kg) }\end{array}$ & $\begin{array}{c}\text { Av-k } \\
(\mathrm{Mg} / \mathrm{kg})\end{array}$ & $\begin{array}{c}\text { CEC } \\
\text { (C,mol/kg) }\end{array}$ & $\begin{array}{c}\mathrm{Ca} \mathrm{CO} 3 \\
\%\end{array}$ & $\begin{array}{c}\text { O.M } \\
\%\end{array}$ \\
\hline \multirow{8}{*}{ Alfalfa } & S19 & 7.3 & 0.37 & 14 & 35.1 & 20 & 0.57 & 1.98 \\
\hline & S4 & 8.1 & 0.42 & 21 & 111.15 & 38 & 2.56 & 2.3 \\
\hline & S12 & 7.12 & 0.27 & 17.5 & 87.75 & 39 & 1 & 2.1 \\
\hline & S13 & 8.1 & 0.21 & 28 & 60.45 & 40 & 2 & 1.6 \\
\hline & S20 & 7.72 & 0.25 & 22.4 & 70.2 & 36 & 2.11 & 1.9 \\
\hline & $\mathrm{S} 21$ & 7.38 & 0.27 & 15.4 & 54.6 & 39 & 0.49 & 2 \\
\hline & S22 & 7.65 & 0.25 & 21 & 46.8 & 42 & 1.48 & 2.16 \\
\hline & S23 & 7.71 & 0.27 & 22.4 & 42.9 & 34.7 & 1.12 & 1.98 \\
\hline
\end{tabular}

\section{Soil salinity and sodicity (EC)}

Data of soil salinity, recorded in Table 3, showed that EC values were 0.16 to $0.88(\mathrm{ds} / \mathrm{m})$. So, the grade of soil salinity varies from "non-saline" to "strongly saline"

The soil can be classified in to the three categories according to the USDA salinity laboratory USDA, 1954 as follows:

1. Non-saline soils (less than $4 \mathrm{ds} \mathrm{m}^{-1}$ ) involve all studied soil samples

2. Moderately saline soils $\left(4-8 \mathrm{ds} \mathrm{m}^{-1}\right)$.

3. Strongly saline soils $\left(8-16 \mathrm{ds} \mathrm{m}^{-1}\right)$.

Results added that EC values trend to decrease with alfalfa in S13, while, they trend to increase with alfalfa in S4, S19. However, EC values of the other soil samples show an irregular trend throughout the soil samples S12, S21 and S23 for alfalfa, which may be attributed to intensive surface irrigation or active upward movement of saline soil solution with drawn as a result of the relatively high saline water table.
With the respect of, soil sodicity, sodium adsorption ratio (SAR) for the saturation extract has been recommended for the sodic soil characterization. Values of SAR have been calculated according to formula introduced by the USDA, (1954).

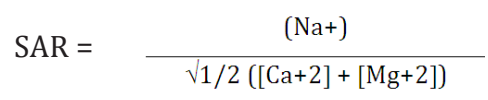

While $\mathrm{Na++}, \mathrm{Ca}++$ and $\mathrm{Mg++}$ in mill mole per liter.

These are given in Table 3. According to SAR, soil could be grouped in to the following categories according to Ghabbour [16].

1. Slightly sodic soils (SAR <20) representing soils of samples.

2. Moderately sodic soils (SAR 20-50) involve all studied soils studied, with exception of soil samples.

3. Strongly sodic soils (SAR $>50)$. 
In general, the moderately sodic soils are mainly located near Birket Qarun and most of the studied area is moderately sodic soils.

\section{Soil calcium carbonate content $\left(\mathrm{CaCO}_{3}\right)$}

The total carbonates content of the studied soil samples have been measured as calcium carbonate content. Data of Table 3 shows the total carbonate content for studied soil samples was ranged from $0.42 \%$ and $3.65 \%$. Soil sample S21 (0.49\%) for alfalfa scored the lowest value. On opposite of, the highest value was obtained in soil sample S4 (2.56\%). Regarding the distribution of carbonate within the soil samples under study, data showed that it tends to increase with alfalfa in S4 and S20, but decrease with alfalfa in S19 and S21, while in the some other soil samples, it exhibited an irregular distribution throughout the soil samples.

\section{Organic matter (OM)}

Data of Table 3 cleared organic matter was generally low (ranged between 0.16 and $2.30 \%$ ) throughout the different soil samples in different area under study. This is a natural characteristic of semi-arid and arid soils, due to the high temperature and dry climate that encourage the decomposition of organic matter. The highest $\mathrm{OM}$ was attained for alfalfa in S4(2.30\%), however, the lowest OM was recorded in S13 (alfalfa). In general, organic matter trended to be high in the surface layer of soil and low in the deepest ones, this pattern of organic matter distribution related to the continuous additions manure and plant residues such as legumes crops to the soil surface.

\section{Total nitrogen (T.N) $(\mathrm{Mg} / \mathrm{kg})$}

Results showing in Table 3 concluded that the total nitrogen content of the studied soil samples ranged between 14 and $49(\mathrm{Mg} / \mathrm{kg})$. The lowest value was recorded in soil sample S19 $(14 \mathrm{mg} / \mathrm{kg})$ for alfalfa. On contrary, the highest value was

Table 4: Chemical analysis soil samples.

\begin{tabular}{|c|c|c|c|c|c|c|c|c|c|c|}
\hline \multirow[t]{2}{*}{ No. of sample } & \multicolumn{4}{|c|}{ Cations (meq/L) } & \multicolumn{4}{|c|}{ Anions (meq/L) } & \multirow[t]{2}{*}{ SAR (Meq/L) } & \multirow[t]{2}{*}{ ESP \% } \\
\hline & $\mathrm{Ca}^{++}$ & $\mathrm{Mg}^{++}$ & $\mathrm{Na}^{+}$ & $\mathbf{K}^{+}$ & $\mathrm{CO}_{3}^{--}$ & $\mathrm{HCO}_{3}^{-}$ & Cl- & $\mathrm{SO4}^{++}$ & & \\
\hline $\mathrm{S}_{4}$ & 3.00 & 0.80 & 36.00 & 0.57 & --- & 1.60 & 1.80 & 40.37 & 26.27 & 27.26 \\
\hline $\mathrm{S}_{12}$ & 1.80 & 0.20 & 36.30 & 0.45 & --- & 1.00 & 1.00 & 36.75 & 36.30 & 34.33 \\
\hline $\mathrm{S}_{13}$ & 1.80 & 0.20 & 29.60 & 0.31 & $-\cdots$ & 1.40 & 0.70 & 29.81 & 29.60 & 29.77 \\
\hline $\mathrm{S}_{19}$ & 1.30 & 0.70 & 37.20 & 0.28 & ----- & 0.74 & 3.00 & 35.80 & 37.20 & 34.90 \\
\hline $\mathrm{S}_{20}$ & 2.33 & 0.80 & 37.20 & 0.48 & $-\cdots$ & 0.88 & 3.19 & 36.82 & 29.76 & 29.89 \\
\hline $\mathrm{S}_{21}$ & 1.33 & 0.60 & 35.20 & 1.00 & --- & 0.80 & 1.80 & 35.53 & 35.91 & 34.08 \\
\hline $\mathrm{S}_{22}$ & 1.70 & 0.50 & 28.40 & 0.47 & ---- & 1.25 & 2.00 & 27.20 & 27.30 & 28.06 \\
\hline $\mathrm{S}_{23}$ & 2.00 & 2.20 & 33.30 & 0.49 & $-\cdots$ & 1.00 & 1.22 & 35.80 & 23.12 & 24.72 \\
\hline
\end{tabular}

\section{Exchangble anions}

According to data of Exchangble anions in (Table 4) cleared that $\mathrm{HCO}_{3}^{-}, \mathrm{Cl}^{-}$and $\mathrm{SO}_{4}$ were generally the principle exchangble anions in the studied soils. Exchangble $\mathrm{HCO}_{3}$ - content ranged between 0.60 and $1.40(\mathrm{meq} / \mathrm{L})$ soil in all the studied soil obtained in soil sample $\mathrm{S} 13(28 \mathrm{mg} / \mathrm{kg})$ for alfalfa. It can be noticed that, total nitrogen content tends to increase it with alfalfa crop (legumes fixed nitrogen) that variations in content and microorganism's activity in the different soil samples under study.

\section{Available potassium $(\mathrm{Mg} / \mathrm{kg})$}

The available potassium content in (Table 3) data revealed that available potassium content ranged from 17.55 to $195(\mathrm{Mg} /$ $\mathrm{kg}$ ). The lowest value was recorded in soil sample S19 (35.1Mg/ $\mathrm{kg}$ ) for alfalfa. On the other hand, the highest value was obtained in soil sample S4 $(111.15 \mathrm{Mg} / \mathrm{kg})$ for alfalfa.

\section{Chemical Analysis of the Soil Study Area Samples}

\section{EXCHANGBLE CATIONS}

Data of exchangeable Cations (Table 4) showed that calcium and magnesium were generally the principle exchangble Cations in the studied soils. Exchangble calcium content ranged between 1.30 and $4.40(\mathrm{meq} / \mathrm{L})$ soil. Whereas exchangeable magnesium content varied from 0.20 and $2.60(\mathrm{meq} / \mathrm{L})$ soil. On the opposite of the monovalent Cations sodium and potassium, which were generally ranged between 14.5 and 54.20 (meq/L) soil (for $\mathrm{Na}^{+}$) and from 0.09 and $1.30\left(\mathrm{meq} / \mathrm{L}\right.$ ) soil (for $\mathrm{k}^{+}$). Exchangeable potassium was the least abundant of the four Cations. Data showed that exhalable Cations were $\mathrm{Na}^{+}>\mathrm{Ca}^{++}>\mathrm{Mg}^{++}>\mathrm{k}^{+}$most of samples.

Data revealed that exchangeable sodium percent (ESP), in most studied soil samples, therefore based on the ESP criteria most soils were classified as non-sodic in some other soils, ESP values were more than $15 \%$, thus being sodic. ESP values tend to increase with soil samples S19, S20, and S21, while the decrease with soil samples S23, but they showed an irregular distribution in the other soil samples.

samples. Whereas the exchangeable $\mathrm{Cl}$ - content varied from 0.60 and 3.85 (meq/L) soil. On the other hand the divalent anion $\mathrm{SO}_{4}$, which was generally ranged between 16.58 and 55.20 (meq/L) soil. Exchangeable $\mathrm{HCO}_{3}$ - was the least abundant of the three anions. Data showed that exhalable Cations were in the order of $\mathrm{SO}_{4}{ }^{++>} \mathrm{Cl}->\mathrm{HCO}_{3}-$. 


\section{Chemical Analysis of the Water Samples}

Water PH: The values of $\mathrm{pH}$ for water samples under study (Table 5), obtained ranged between 7.16 and 8.10, the change in $\mathrm{pH}$ values, data revealed that a slightly increase with gas factory area and Abu Nashaba village, Soil $\mathrm{pH}$ values may be indicated that these studied water are base- saturated since all their $\mathrm{PH}$ values are over 7.0.

Water salinity and sodicity (EC) : Data of water salinity, as expressed in terms of water paste (Table 5), showed values EC from 0.26 to 0.82 (ds/m). So, the grade of water salinity varies from "Low salinity or high quality water "to" Very high salinity or very low quality". The water can be classified in to the three categories according to the USDA salinity laboratory USDA, 1954 as follows:

1. Low salinity or high quality water (less than $0.25 \mathrm{ds}$ $\mathrm{m}^{-1}$ )

2. Medium salinity or quality water $\left(0.25-0.75 \mathrm{ds}^{-1}\right)$. involve all studied water samples with the exception water sample (Albarka basin and Al madaor sample)

3. High salinity or low quality water $\left(0.75-2.25 \mathrm{ds} \mathrm{m}^{-1}\right)$, representing water samples of (Albarka basin and $\mathrm{Al}$ madaor sample) only.

4. Very high salinity or very low quality (more than 2.25 ds $\mathrm{m}^{-1}$ )

Exchangble cations: Table 5 showed that exchangble Cations calcium and magnesium were generally the principle exchangble Cations in the chemical analysis water. Exchangble calcium content ranged between $3.6(\mathrm{meq} / \mathrm{L})$ water at Al barka basin and $\mathrm{Al}$ madaor location and $9.40(\mathrm{meq} / \mathrm{L})$ water at gas factory area in all the studied water samples. Whereas the exchangeable magnesium content varied from 1.00 (meq/L) and 4.20 (meq/L) water at the same previous locations. On contrary, the monovalent Cations sodium and potassium, which were generally ranged between $1.87(\mathrm{meq} / \mathrm{L})$ at $\mathrm{Al}$ barka basin and $\mathrm{Al}$ madaor location and $6.40(\mathrm{meq} / \mathrm{L})$ water at $\mathrm{Abu}$ Nashaba village location (for $\mathrm{Na}^{+}$) and $0.44(\mathrm{meq} / \mathrm{L})$ water at Alkhvoj village (for k+). Exchangeable potassium was the least abundant of the four Cations. Data showed that exhalable Cations were $\mathrm{Ca}^{++}>\mathrm{Na}^{+}>\mathrm{Mg}^{++}>\mathrm{k}^{+}$in most of water samples.

Exchangble anions: Data presented in (Table 5) clarified that exchangble anions of $\mathrm{HCO}_{3}{ }^{-}, \mathrm{Cl}$ - and $\mathrm{SO}_{4}$ were generally the principle exchangble anions in the studied of water samples. Exchangble $\mathrm{HCO}_{3}$ - content ranged between 2.00 (meq/L) water at $\mathrm{Al}$ barka basin and $\mathrm{Al}$ madaor location in all the studied water samples. Whereas the exchangeable $\mathrm{Cl}$ - content varied from $0.80(\mathrm{meq} / \mathrm{L})$ water at $\mathrm{Al}$ barka basin and $\mathrm{Al}$ madaor location. On the other hand the monovalent anion SO4. Exchangeable $\mathrm{HCO}_{3}$ - was the least abundant of the three anions. Data revealed that exhalable Cations were $\mathrm{SO}_{4}++>\mathrm{Cl}->\mathrm{HCO}_{3}$ - in most of water samples under study. Regarding, sodium adsorption ratio (SAR) in most water samples of the study area. Values of SAR have been calculated according to formula introduced by the USDA, (1954).

$\mathrm{SAR}=$

$(\mathrm{Na}+)$

$$
\sqrt{1 / 2}([\mathrm{Ca}+2]+[\mathrm{Mg}+2])
$$

While $\mathrm{Na}^{++}, \mathrm{Ca}^{++}$and $\mathrm{Mg}^{++}$in mill mole per liter.

These are given in Table 3. According to SAR, soil could be grouped in to the following categories according to Ghabbour [16].

1. Slightly sodic water $(S A R<10)$ involves all studied water samples.

2. Moderately sodic water (SAR 10-18)

3. High sodic water (SAR 18-26).

4. Very High sodic water (SAR $>26)$.

Finally, most of studied area slightly sodic water

Table 5: the chemical analysis water samples.

\begin{tabular}{|c|c|c|c|c|c|c|c|c|c|c|c|}
\hline \multirow{2}{*}{ Location No. Samples } & \multirow{2}{*}{$\begin{array}{c}\text { pH } \\
(1: 2.5) \\
\end{array}$} & \multirow{2}{*}{$\begin{array}{c}\text { EC } \\
\text { (ds } / \mathrm{m})\end{array}$} & \multicolumn{4}{|c|}{ Cations (meq/L) } & \multicolumn{4}{|c|}{ Anions (meq/ L) } & \multirow{2}{*}{ SAR } \\
\hline & & & $\mathrm{Ca}++$ & $\mathrm{Mg++}$ & $\mathrm{Na}+$ & $\mathbf{K}+$ & Co3-- & HCo3- & CL+ & So4++ & \\
\hline $\begin{array}{l}\text { 1. Albarka basin and Al madaor } \\
\text { sample }\end{array}$ & 7.55 & 0.82 & 3.6 & 1.00 & 1.87 & 0.25 & ----- & 2.00 & 0.80 & 3.92 & 1.10 \\
\hline 5. Abu Nashaba village & 8.10 & 0.73 & 4.50 & 3.40 & 6.40 & 0.39 & ----- & 3.25 & 5.50 & 5.94 & 3.23 \\
\hline 6. Alkhvoj village & 7.25 & 0.32 & 4.75 & 2.66 & 3.42 & 0.44 & $-\cdots-$ & 2.50 & 2.55 & 6.22 & 1.78 \\
\hline
\end{tabular}

General Descriptive Statistics of Soil Indicators Under Study

The data obtained in Table 6 show that mean data of 21 SQ indicators effects on Alfalfa productivity. Results concluded that, three physical SQ indicators (FS, TP, and FC) only were significantly different $(39.17 \pm 3.44), \quad(49.77 \pm 3.24)$, and $(24.94 \pm 3.69)$ respectively, compared with other physical SQI. Also, these three SQI were recorded the largest relative weighted

and most effective on alfalfa productivity. Both FS, TP and FC had affected by $(1.23 \%, 1.57 \%$, and $0.79 \%)$ respectively, on alfalfa productivity.

Results also cleared that, CEC chemical SQI indicator had significant effect $(37.58 \pm 3.19)$ by relative weighted $1.18 \%$ on alfalfa yield comparing with other chemical SQ indicators which recorded the lowest relative weighted values and lowest effective on alfalfa productivity. Our results in agreement with 
Bhardwaj et al. [17] and Zornoza et al. [18]. With regard to, regression coefficients obtained between SOC, AWHC, AC, RFC, $\mathrm{pH}$, and EC showed significant relationships with soil physical and chemical indicators. These variables positively impacted the physical quality of soil by improving soil structural stability and biological properties as reported by many authors Shukla et al. [19]; Liu et al. [11]. Because of SOC for soil, it was selected in this study. Table 6 Descriptive statistic of soil quality indicators under study $(\mathrm{n}=21)$.

Table 6: Descriptive statistic of soil quality indicators under study $(n=21)$.

\begin{tabular}{|c|c|c|c|c|}
\hline \multicolumn{2}{|l|}{ Mean } & $\begin{array}{c}\text { Std. } \\
\text { Deviation }\end{array}$ & Weight & Sample No. \\
\hline Alfalfa productivity & 32.9389 & 1.8581 & 0.104 & 8 \\
\hline CS & 7.525 & 2.32056 & 0.024 & 8 \\
\hline FS & 39.175 & 3.44207 & 0.123 & 8 \\
\hline SILT & 22.45 & 6.21243 & 0.071 & 8 \\
\hline CLAY & 30.85 & 4.45774 & 0.097 & 8 \\
\hline R.D & 2.6687 & 0.05592 & 0.008 & 8 \\
\hline B.D & 1.3188 & 0.0799 & 0.004 & 8 \\
\hline Т.P & 49.7712 & 3.24196 & 0.157 & 8 \\
\hline Q.D.P & 14.35 & 2.67795 & 0.045 & 8 \\
\hline S.D.P & 10.4375 & 1.2671 & 0.033 & 8 \\
\hline W.H.P & 13.2875 & 1.93127 & 0.042 & 8 \\
\hline F.C & 24.9813 & 3.69478 & 0.079 & 8 \\
\hline W.P & 11.6938 & 1.91953 & 0.037 & 8 \\
\hline H.C & 4.1625 & 2.44335 & 0.013 & 8 \\
\hline M.W.D & 2.1262 & 0.77012 & 0.007 & 8 \\
\hline E.C & 0.2738 & 0.06232 & 0.001 & 8 \\
\hline PH & 7.6938 & 0.33088 & 0.024 & 8 \\
\hline $\mathrm{OM}$ & 2.0125 & 0.20645 & 0.006 & 8 \\
\hline $\mathrm{CaCO} 3$ & 1.485 & 0.68694 & 0.005 & 8 \\
\hline $\mathrm{CEC}$ & 37.5875 & 3.19662 & 0.118 & 8 \\
\hline$A v-k$ & 0.3362 & 0.11987 & 0.001 & 8 \\
\hline T.N & 0.2987 & 0.05357 & 0.001 & 8 \\
\hline
\end{tabular}

Physical and chemical SQI

Between CS \& RD ( $\mathrm{r}=-0.65), \mathrm{CS} \& \operatorname{SDP}(\mathrm{r}=-0.65), \mathrm{FS} \&$ Silt $(\mathrm{r}=-0.868), \mathrm{FS} \& \mathrm{EC}(\mathrm{r}=-0.786) \&$ FS, CaCO3 $(\mathrm{r}=-0.60)$, Silt \& Clay $(\mathrm{r}=-0.732)$, Clay \& QDP $(\mathrm{r}=-0.708)$, Clay \& EC $(\mathrm{r}=-$ 0.678), Clay \& OM ( $\mathrm{r}=-0.776)$, RD \& QDP $(\mathrm{r}=-0.67)$, B.D \& T.P $(r=-0.771)$, B.D \& WHP ( $r=-0.765)$, B.D \& FC ( $r=-0.727)$, B.D \&WP $(\mathrm{r}=$ - 0.63), QDP \& SDP $(\mathrm{r}=-0.69), \mathrm{HC} \& \operatorname{MWD}(\mathrm{r}=-0.723)$. In this study, both EC $(r=0.966), \mathrm{OM}(\mathrm{r}=0.700), \mathrm{Av}-\mathrm{k}(\mathrm{r}=0.660)$, is also showing significant correlation $(\mathrm{P}<0.05)$ with Silt. While, FC $(r=0.757)$, WP $(r=0.871)$, HC $(r=0.845)$ representing high positive significant correlation $(\mathrm{P}<0.01)$ with $\mathrm{RD}$. Results also concluded that, TP showing strong positive correlation $(\mathrm{P}<$ $0.01,0.05)$ with FC ( $r=0.837)$, WHP ( $r=0.794)$, WP $(r=0.813)$, HC ( $r=0.733)$, and EC ( $r=0.670)$. While, QDP showing moderate positive correlation with OM $(\mathrm{r}=0.640)$. As for, WHP indicator, results cleared that it is showing highly positive correlation both FC ( $\mathrm{r}=0.960)$, WP $(\mathrm{r}=0.841)$, and HC ( $\mathrm{r}=0.719)$. Regarding FC showing highly correlation $(\mathrm{P}<0.01)$ with WP $(\mathrm{r}=0.959)$ and HC $(r=0.857)$, in addition, WP represented highly significant with HC ( $\mathrm{r}=0.926)$, Moreover, EC showing high correlation $(\mathrm{P}<$ $0.05)$ with $\mathrm{OM}(\mathrm{r}=0.735)$ and Av-k ( $\mathrm{r}=0.757)$, while $\mathrm{PH}$ gives high significant $(\mathrm{P}<0.05)$ with $\mathrm{CaCO} 3(\mathrm{r}=0.766)$ and $\mathrm{TN}(\mathrm{r}=0.755)$, Although, $\mathrm{CaCO} 3$ showing moderate significant correlation $(\mathrm{P}<$ 0.05) with TN (r=0.650) only.

Aparicio \& Costa [10] who found there was correlation among OC and some indicators such asBulk density, porosity, HC and MWD consider in this study for BD and porosity. A significant relationship with soil physical and chemical indicators. These variables positively impacted the physical quality of soil by improving soil structural stability and biological properties as reported by many authors $[11,19]$. Because of SOC for soil, it was selected in this study. Thus, it can be concluded that SOC is one of key indicators affecting the soil quality and sustainability in the studied area, which findings Govaerts et al. [20], Lal, [21], Gregorich et al. [22]. In addition, Lee et al. [23] reported indices monitor soil sustainability changes instead of using the common definitions of SQI like physical and chemical properties and their processes.

\section{Influence of Physical SQ Indicator on Alfalfa Productivity}

Data recorded in Table (7) revealed that, insignificant relationship was observed between soil physical parameters and yieldofalfalfa.

\section{Relationship among Chemical SQI and alfalfa productivity}

Results mentioned in Table (7) and Figures (1-3), showed that, Correlation matrix between alfalfa yield and chemical soil quality indicators. Results concluded that, insignificant linear relationship correlation was observed between alfalfa productivity and most of chemical parameters under study such as (EC, CaCo3, CEC, and Av. k) ( $\mathrm{r}=-0.021,0.490,-0.470$, and 0.000) respectively, on the opposite, both of $\mathrm{PH}, \mathrm{OM}$ and T.N indicators showing a significant positive linear relationship correlation (P $<0.05, \mathrm{r}=0.680,0.520,0.650$ ) respectively.

Semi results confirmed by Mohanty et al. [24], reported that accumulation $\mathrm{OM}$ can increasing SQ by reducing BD, surface sealing and crust formation as well as raise aggregate stability Somasundaram et al. [25], cation exchange capacity, nutrient cycling, and biological activity [26]. Based on fertilizers and other input can be decreased by increasing biological nitrogen fixation [21]. Also, Balota et al. [27] found that, the applied variables range from those which are more common and discussed, like (OC) and (TN) components, to those which are related to biological activities and which are more recent, such as determining enzyme activity (EA). The latter are particularly useful for monitoring soil quality, since determining biochemical 
parameters is related to key microbial processes used to preserve particulate fraction. Eiza et al. [29] says it is an indicator which its metabolic activity [28]. Eiza et al. [29], Ferreras et al. [30] and is more effective than the TOC for identifying the effects on the De Figueiredo et al. [31] agree that most of the changes which soil [32-37].

occur during different soil managements take place in the OC's

Table 7: Correlation relationship matrix between soil quality and alfalfa productivity.

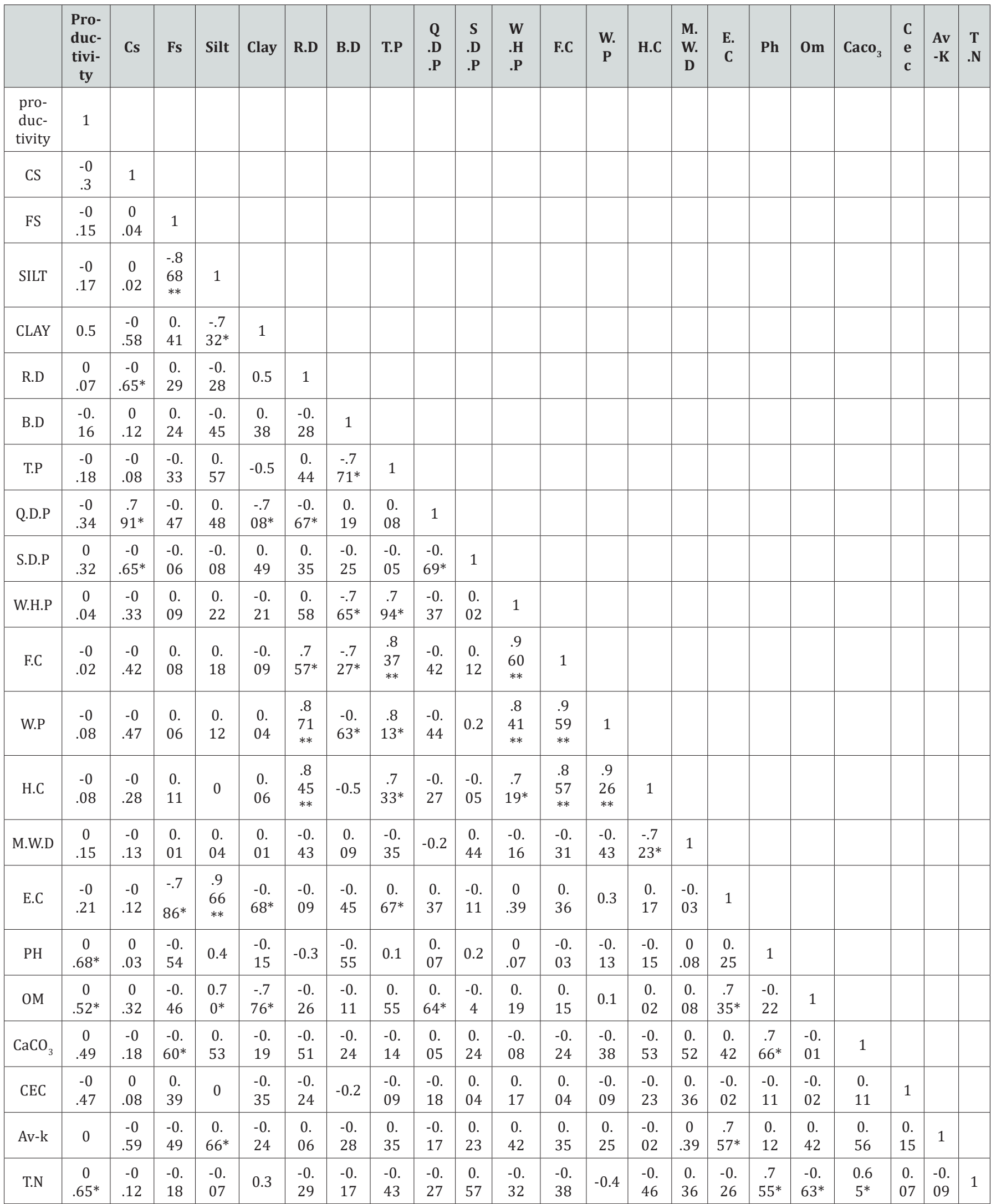




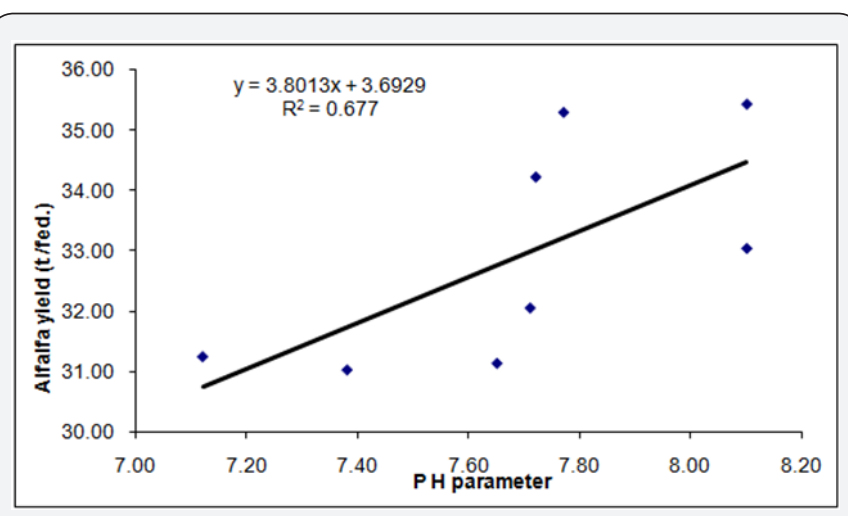

Figure 1: The liner relationship correlation between chemical $\mathrm{pH} \mathrm{SQI}$ and alfalfa yield (t/fed.).

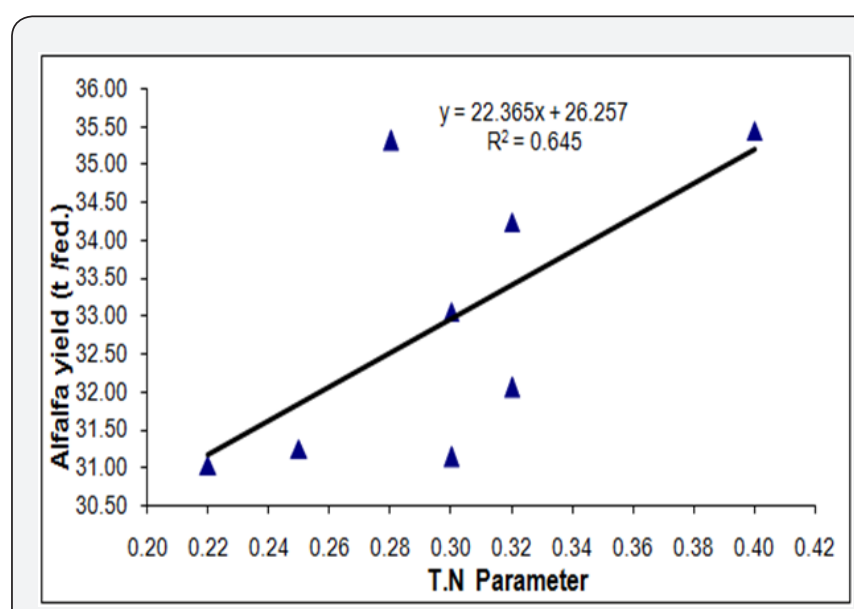

Figure 2: The liner relationship correlation between total nitrogen (T.N) and alfalfa yield (t/fed.).

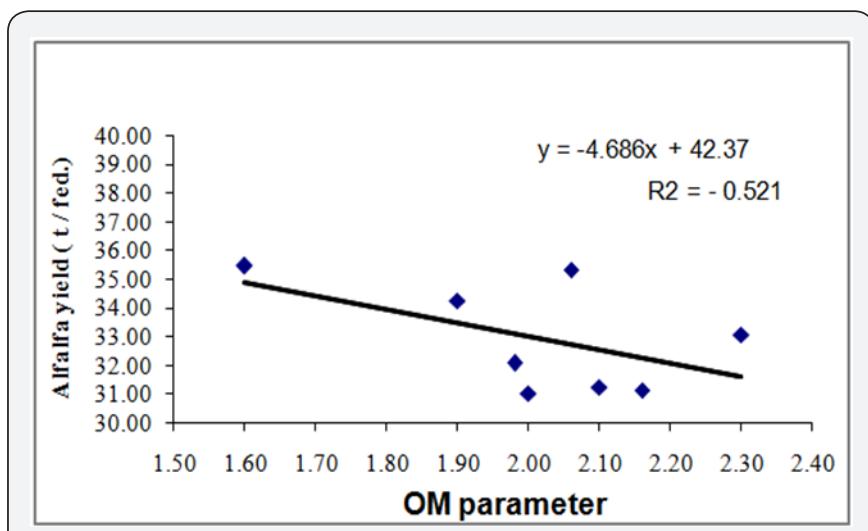

Figure 3: The liner relationship correlation between organic matter (OM) and alfalfa yield (t/fed.).

\section{References}

1. Doran JW, Parkin BT (1994) Defining and assessing soil quality. In Doran JW, Coleman DC, Bezdicek DF, Stewart BA (Eds.), Defining Soil Quality for a Sustainable Environment. Soil Science Society of America, Inc., Madison, WI, USA, pp: 3-21.

2. Wienhold BJ, Andrews SS, Karlen DL (2004) Soil quality: A review of the science and experiences in the USA. Environ Geochem Health 26(23): $89-95$.
3. Karlen DL, Mausbach JW, Doran JW, Cline RG, Harris RF, et al. (1997) Soil quality: A concept, definition and framework for evaluation. Soil Sci Soc Am J 61(1): 4-10.

4. Drury CF, Zhang TQ Kay BD (2003) The non-limiting and least limiting water range for soil nitrogen mineralization. Soil Sci Soc Am J 67(5): $1388-1404$

5. Singh MJ, Khera KL (2009) Physical indicators of soil quality in relation to soil erodibility under different land uses. Arid Land Res Manag 23(2): 152-167.

6. Reynolds WD, Drury CF, Tan CS, Fox CA, Yang XM (2009) Use of indicators and pore volume-function characteristics to quantify soil physical quality. Geoderma 152(3-4): 252-263.

7. Larson WE, Pierce FJ (1994) The dynamics of soil quality as a measure of sustainable management. Defining Soil Quality for a Sustainable Environment. Soil Science Society of America, Madison, Wisconsin, USA, pp. 37-52.

8. Karlen DL, Gardner JC, Rosek MJ (1998) A soil quality framework for evaluating the impact of CRP. J Prod Agric 11(1): 56-60.

9. Gomez AA, Kelly DES, Syers JK, Coughlan KJ (1996) Measuring sustainability of agricultural systems at farm level. In: Doran JW, Jones AJ (Eds.), Methods for assessing soil quality. SSSA Special Publication Number 49, Soil Science Society of America, Inc., Madison, USA, pp. 401-410.

10. Aparicio V, Costa JL (2007) Soil quality indicators under continuous cropping systems in the Argentinean Pampas. Soil Till Res 96(1-2): 155-165.

11. Liu Z, Zhou W, Shen J, Li S, Ai C (2013) Soil quality assessment of yellow clayey paddy soils with different productivity. Biol Fert Soils 50(3): 537-548.

12. Shukla MK, Lal R, Ebinger M (2004) Principal component analysis for predicting corn biomass and grain yields. Soil Sci 169(3): 215-224.

13. Page AL, Miller RH, Keeny DR (1982) Methods of soil analysis. Part $\pi$. Chemical and microbiological properties. ( $2^{\text {nd }}$ edn), Amer Soc Agron Monograph no. 9.2 Madison, Wisconsin, USA.

14. Klute A (1986) Methods of Soil Analysis. Part1. Physical and Mineralogical methods. ( $2^{\text {nd }}$ edn), Amer Soc Agron Monograph no. 9 Madison, Wisconsin, USA, pp. 1188.

15. Saxton KE, Rawls WJ (2006) Soil water characteristic estimates by texture and organic matter for hydrologic solutions. Soil Science Society of America Journal 70: 1569-1578.

16. Ghabbour EA (1988) Understanding Humic Substances: Advanced Methods, Properties and Uses. Royal Society of Chemistry, Cambridge and Soil Science 166(12): 950-951

17. Bhardwaj AK, Jasrotia P, Hamilton SK, Robertson GP (2011) Ecological management of intensively cropped agro-ecosystems improves soil quality with sustained productivity. Agriculture, Ecosystems and Environment 140(3-4): 419-429.

18.Zornoza R, Mataix-Solera J, Guerrero C, Arcenegui V, Mayoral AM (2007) Soil properties under natural forest in the Alicante Province of Spain. Geoderma 142(3-4): 334-341.

19. Shukla MK, Lal R, Ebinger M (2006) Determining soil quality indicators by factor analysis. Soil till Res 87(2): 194-204.

20. Govaerts B, Sayre KD, Deckers J (2006) A minimum data set for soil quality assessment of wheat and maize cropping in the highlands of Mexico. Soil Till Res 87(2): 163-174.

21. Lal R (2003) Cropping Systems and Soil Quality. J Crop Prod 8(1-2): 33-52.

22. Gregorich EG, Carter MR, Doran JW, Pankhurst CE, Dwyer LM (1997) Biological attributes of soil quality. In: Gregorich EG, Carter MR (Eds.), 
Soil Quality for Crop Production and Ecosystem Health. New York, USA, pp. 81-114.

23. Lee SB, Lee CH, Jung KY, Park KD, Lee D, et al. (2009) Changes of soil organic carbon and its fractions in relation to soil physical properties in a long-term fertilized paddy. Soil \& Tillage Research 104(2): 227-232.

24. Mohanty M, Painuli DK, Misra AK, Ghosh PK (2007) Soil quality effects of tillage and residue under rice-wheat cropping on a vertisol in India. Soil Till Res 92(1-2): 243-250.

25. Somasundaram J, Singh RK, Ali S, Sethy BK, Singh D, et al. (2013) Soil aggregates and other properties as influenced by different long term land uses under table landscape topography of Chambal region, Rajasthan, India, 40(3): 212-217.

26. Karlen DL, Andrews SS (2004) Soil quality, fertility, and healthHistorical context, status and perspectives. In: Schjønning P (Ed.), Managing soil quality: Challenges in modern agriculture. CABI Int Publ, Oxon, UK, pp. 17-33.

27. Balota LE, Kanashiro M, Filho CA, Andrade SD, Dick RP (2004) Soil enzyme activities under long-term tillage and crop rotation systems in Sub Tropical Agro-Ecosystems. Brazilian Journal of Microbiology 35(4): 300-306.

28. Trasar-Cepeda C, Leiros M, Seoane S, Gil-Sotres F (2008) Biochemical properties of acid soils under crop rotation. Appl Soil Ecol 39(2): 133143.
29. Eiza M, Fioriti N, Studdert G, Echeverría H (2005) Fractions of organic carbon in the topsoil: effect of cropping systems and nitrogen fertilization. CI Ground (Argentina) 23(1): 59-67.

30. Ferreras L, Toresani S, Bonel B, Fernández E, Bacigaluppo S, et al. (2009) Chemical and biological indicators of soil quality in different management parameters. CI Ground (Argentina) 27(1): 103-114.

31. De Figueiredo CC, Siqueira Resck DV, Carbone Carneiro MA (2010) Labile and stable fractions of soil organic matter under management systems and native Cerrado. R Bras Ci Solo 34(3): 907-916.

32. Araujo ASF, Luiz FCL, Santos VB, Carneiro RFV (2009) Soil Microbial Activity in Conventional and Organic Agricultural Systems. Sustainability 1(2): 268-276.

33. Mohanty M, Sinha NK, Hati KM, Chaudhary RS, Painuli DK (2013) Stability of Soil Aggregates under Different Vegetation Covers in a Vertisol of Central India. J Agric Phys 12: 1-12.

34. Sigma P (2012) Scientific Software Solutions Internationals; Sigma plot version 12.

35. Six J, Conant RT, Paul EA, Paustian K (2002) Stabilization mechanisms of soil organic matter: Implications for C-saturation of soils. Plant Soil 241(2): 155-176.

36. SPSS (2014) IBM SPSS, Version 21.0, Chicago, USA.

37. USDA (1954) Diagnosis and Improvement of saline and Alkali soils. US Dept of Agric, Hand Book No. 60 78(2): 154.

Your next submission with Juniper Publishers
will reach you the below assets
- Quality Editorial service
- Swift Peer Review
- Reprints availability
- E-prints Service
- Manuscript Podcast for convenient understanding
- Global attainment for your research
- Manuscript accessibility in different formats
( Pdf, E-pub, Full Text, Audio)
- Unceasing customer service
Track the below URL for one-step submission
https://juniperpublishers.com/online-submission.php

